\title{
A CRITICAL ANALYSIS OF MALAYSIAN HIGHER EDUCATION INSTITUTIONS' RESPONSE TOWARDS COVID-19: SUSTAINING ACADEMIC PROGRAM DELIVERY
}

\author{
NORZAINI AZMAN*1 AND DORIA ABDULLAH ${ }^{2}$ \\ ${ }^{1}$ Faculty of Education, Universiti Kebangsaan Malaysia. ${ }^{2}$ School of Education, Faculty of Social Sciences and Humanities, \\ Universiti Teknologi Malaysia.
}

*Corresponding author: norzai12@ukm.edu.my

Submitted final draft: 4 September 2020 Accepted: 10 September $2020 \quad$ http://doi.org/10.46754/jssm.2021.01.008

\begin{abstract}
The COVID-19 global pandemic has caused massive disruptions in many sectors of society including higher education. Although the mainstream news outlets and social media have discussed how Malaysia's higher education system coped with the disruptions caused by COVID-19, a fuller narrative needs to be properly documented. This qualitative narrative review involved an analysis of various types of publications including scholarly articles, world organizations' reports, university documents as well as commentaries and reports from mainstream news outlets and social media that directly focus on the topic. It is evident from the review that Malaysian HEIs' priority was in safeguarding student and staff welfare in terms of their health and safety. While providing emergency aid to students and support for institutions, the Ministry of Higher Education together with HEIs developed administrative measures to safeguard the delivery of programmes through remote online learning. The analysis confirmed that while online learning is considered appropriate during an emergency period, the digital divide clearly still exists, posing the greatest challenge to Malaysia's recovery post COVID-19. The critical review on the immediate impacts of the pandemic on teaching and learning point to key recommendations for leadership, student welfare, and the importance of flexible education and evidence-based policymaking.
\end{abstract}

Keywords: COVID-19, higher education, teaching and learning, online learning, student affairs.

\section{Introduction}

In today's interconnected world, economic, environmental, health, social and education issues experienced in one country are capable of escalating into global issues within a short period of time. When the COVID-19 virus was first reported in December 2019, the world was not prepared for what followed immediately. By the end of January 2020, the virus had spread to Asia, Europe and America, morphing into a global pandemic. Since then, the modern socio-economic ecosystem has been forced into an extended period of shutdown, impacting healthcare, education, culture and society in the short-, medium- and long term (World Bank, 2020). The shutdown has also revealed starkly the extent that the wellbeing of our planet and its people, particularly in relation to climate crisis and loss in nature diversity, has been affected by the modern industry and economic system. We are truly interdependent across all borders and oceans and it is critical that we build resilience and sustainability of communities and societies in order to weather other possible crises in the future.

Education, including higher education, has been directly impacted by the COVID-19 global pandemic. As of 8 April 2020, 220 million post-secondary students across 175 countries experienced severe disruptions to their education, as colleges and universities were forced to close in an effort at containing the spread of the virus. This constitutes 13 per cent of the total number of students affected globally (World Bank, 2020; UNESCO, 2020). An immediate response by higher education institutions (HEIs) was to pivot teaching and learning ( $\mathrm{T} \& \mathrm{~L}$ ) activities online as much as possible, giving rise to various new terms for the process, such as "remote learning", "home-based learning". and "emergency remote education", 
besides existing terms for technology-enabled learning at a distance, such as "online learning" and "distance learning" (Bozkurt \& Sharma, 2020). HEIs also suspended all physical faceto-face teaching and meetings, closing of all buildings to physical access and keeping their students at home. International students were forced to remain in their host countries, or were repatriated by their respective governments, as borders were closed for international travel. The immediate main concern of policy makers, administrators, and practitioners was to secure the well-being of their students and staff, as well as to ensure continuity in academic delivery in the foreseeable future.

Evidently, higher education continues to grapple with the implications of the pandemic on teaching and learning, research and innovation, as well as the education outcomes of its programmes (World Bank, 2020). A quick assessment of the COVID-19 disruption has exposed many short and long-term challenges at both system and institution levels. Countries exporting education have seen sharp decreases in revenues, since reduced mobility affects future trajectories in international student enrolment (World Bank, 2020). Graduates enter the job market with uncertainty about career prospects. HEIs have realized that they require immediate investment to improve not only infrastructure in supporting distance and blended learning models, but also the capacity of its academic staff and students to manage $\mathrm{T} \& \mathrm{~L}$ activities. Students are unable to engage in active learning due to limitations in internet access and digital devices (UNESCO, 2020). Moving forward, higher education systems must ensure that there is some form of continuity to sustain core functions and operations of its HEIs.

Although the story of Malaysia's higher education system in coping with the COVID-19 crisis has been largely discussed in the mainstream news outlets and social media, a more complete narrative needs to be properly documented. Arguably, even while HEIs have somewhat adjusted to the new normal in academic delivery and operations, many issues have yet to be resolved. This article will narrate Malaysia's experience in responding to and managing the unpredictable and extended disruption of the COVID-19 pandemic to its higher education system, focusing in particular on how HEIs sustained their teaching and learning ( $\mathrm{T} \& \mathrm{~L}$ ) activities throughout the Movement Control Order (MCO) period imposed by the government since 18 March 2020, just entering the sixth phase of implementation at the point of writing. Data has been gleaned from consolidated published articles in scholarly literature, world organisation reports, commentaries from the mainstream news outlets and social media that directly focus on the topic. In addition, the authors consulted various supplementary documents made available by the HEIs on their management and current practices of $\mathrm{T} \& \mathrm{~L}$ during the MCO period.

The article is presented in three sections. It starts with a brief introduction of the $\mathrm{T} \& \mathrm{~L}$ component of the Malaysian higher education system, followed by a chronology of events describing responses of the system throughout the COVID-19 MCO period, as well as an indepth review of stakeholders' experience in $\mathrm{T} \& \mathrm{~L}$ from the opinion and reflection papers and analyses of policies and guidelines. In this context, "stakeholder" is operationally defined as those who are directly involved in $\mathrm{T} \& \mathrm{~L}$ processes of higher education, including students, academic staff, and administrators, academic leaders and policy makers at both institutional and national levels. Finally, a list of lessons learnt, and implications for practice are presented, which would hopefully pave the way for more constructive, evidence-based, sectorwide and inclusive involvement of stakeholders in rejuvenating the higher education system post MCO.

As a narrative review, this paper has three objectives: 1) to critically reflect on the experiences over the past few months; 2) to feature key takeaways on $\mathrm{T} \& \mathrm{~L}$ that can be shared with the global higher education community; and 3) to initiate conversations between policy makers and practitioners on sustainable practices to mitigate further shocks and impacts to $\mathrm{T} \& \mathrm{~L}$ in the future. 


\section{Materials and Method}

The content of this review article is based on a narrative non-systematic review method, which is a qualitative research design used to narrate and discuss Malaysian HEIs' experience in responding to and managing the disruption caused by COVID-19, with the aim of providing a timely review of the COVID-19 impact on higher education. This method was deemed appropriate due to the complexity of the issues. A non-systematic narrative review summaries different primary studies from which conclusions may be drawn into a holistic interpretation contributed by the reviewers' own experience and observations (Collins \& Fauser, 2005). Given the lack of empirical literature on the impact of the COVID-19 pandemic on higher education and that the pandemic is a new, unprecedented phenomenon, the narrative review approach draws its strength from the supplemented analysis based on the authors' self-knowledge, reflective practice and acknowledgement of shared educational phenomena (Baumeister \& Leary, 1997, Jones, 2004,).

Since original full-length empirical studies written in English were limited, reviews, editorials and commentaries and other documents deemed appropriate were also considered. Thus, the search included grey literature comprising experts' and practitioners' opinions published in bulletins and newsletters, as well as reports on the practical aspects of $\mathrm{T} \& \mathrm{~L}$ by students and professionals (academics and managers) published in various media outlets. The authors also consulted various supplementary documents made available by the HEIs on their management of T \& L during the lockdown to get an overall view of the situation. As purported by Greenhalgh et al. (2005), when trying to make sense of a complex concept or phenomenon, it is important to review literature from multiple sources and from diverse disciplines.

Data collection employed four main electronic databases, i.e., EBSCOHOST, Scopus, and Google Scholar and Google, using the main key search words 'COVID-19 and higher education; COVID-19 and T \& L in HEIs', 'COVID-19 and Malaysian HEIs' to identify the relevant records that could provide readily comprehensible accounts of the pandemic. From the contents of the documents reviewed (see examples in Table 1), certain themes were developed and elaborated on accordingly. The review also highlights current controversies and contradictory impacts and crucial gaps in knowledge, in order to impart a more complete understanding of current thinking and responses

Table 1: Sources Used for Narrative Review

\begin{tabular}{|c|c|c|}
\hline Source Type & Example & $\begin{array}{c}\text { Total Number } \\
\text { of Document }\end{array}$ \\
\hline Scholarly Articles & $\begin{array}{l}\text { Wang C. and Zhao H. (2020). The Impact of COVID-19 } \\
\text { on Anxiety in Chinese University Students, Frontiers in } \\
\text { Psychology, 11:1168. doi: } 10.3389 / \text { fpsyg. } 2020.01168\end{array}$ & 17 \\
\hline $\begin{array}{l}\text { Government } \\
\text { Information/Guidelines }\end{array}$ & $\begin{array}{l}\text { Kementerian Pengajian Tinggi, Malaysia. 2020. Pengendalian } \\
\text { Program Akademik di Universiti Awam (UA) dan Institusi } \\
\text { Pendidikan Tinggi Swasta (IPTS) }\end{array}$ & 10 \\
\hline $\begin{array}{l}\text { University Document } \\
\text { From their Websites }\end{array}$ & $\begin{array}{l}\text { Universiti Malaysia Sarawak. (2020). COVID-19 response: A } \\
\text { quick guide for UNIMAS academics }\end{array}$ & 20 \\
\hline $\begin{array}{l}\text { Higher Education News/ } \\
\text { Bulletin }\end{array}$ & $\begin{array}{l}\text { Ross, J. ( } 2020 \text {, June, 4). Pandemic Confirms face-to-face } \\
\text { teaching is here to stay, Times Higher Education }\end{array}$ & 5 \\
\hline Media Articles & $\begin{array}{l}\text { Rafidi, R. (2020, June 19). Missing the campus experience. } \\
\text { News Straits Times }\end{array}$ & 15 \\
\hline Reports \& Papers & $\begin{array}{l}\text { UNESCO. (2020, March 13). COVID-19 educational } \\
\text { disruption and response. }\end{array}$ & 4 \\
\hline
\end{tabular}


of the HEIs and the system. In some instances, the reviews and critical analyses are complemented by previous empirical findings from scholarly publications on related aspects of T \& L.

\section{Teaching and Learning ( $T \& L)$ in the Malaysian Higher Education System}

"Higher education" in Malaysia, as described by the Malaysian Qualifications Framework (MQF) 2.0, is tasked to provide training and education programmes that enable individuals to advance their careers, professional practices and employment prospects in various sectors (Malaysian Qualifications Agency, 2017). These programmes are structured based on eight levels of learning achievement: Certificate (Level 1-3), Diploma and Advanced Diploma (Level 4-5) and Bachelor, Master and Doctoral degrees (Level 6, 7 and 8). Higher education is also tasked to provide progression and flexible learning pathways to learners with various needs and backgrounds, in order to widen access to education for lifelong learners. This is done through Accreditation of Prior Experiential Learning (APEL), or recognition of prior learning for professionals with skills sets accrued throughout their working experience. Ultimately, the Malaysian higher education system is expected to contribute to Malaysia's social, economic and political development, through the nurturing of quality citizens, a highly skilled and talented workforce, and production of new knowledge (Ministry of Education, 2015).

The Malaysian higher education landscape is diverse, comprising over 20 public universities, 36 polytechnics, 99 community colleges and 450 private universities and colleges across the country. In $2019^{1}$, these institutions served over 552,702 students, of which 173,000 were international students. A typical academic year for these students comprises two 14-week semesters, and they are required to take an average of three to seven courses per semester, depending on full- or part-time mode. By the end of their study, they would have completed a minimum number of graduating credits required under the MQF: at least 90 credits for diploma and a minimum of 120 credits for degree. Each graduating credit, equivalent to 40 notional hours of Student Learning Time (SLT), could be delivered through conventional learning, blended learning, or full online learning, subject to the percentage allocation of face-to-face time determined under the MQF.

The fundamental block for each academic programme and course (or subject) is learning outcome, defined as “... statements on what students should know, understand and can do upon successful completion of a period of study, which generally lead to a qualification or part of a qualification..." (Malaysian Qualifications Agency, 2017). These statements outline specific skills and knowledge that the students can perform in professional, educational, and other life contexts as well as clarify the demands and complexities of learning by each level. The learning outcomes must include both declarative (e.g., facts, theories and rules) and functional (e.g., communication skills, organisation skills) knowledge in order to develop learners' objective reasoning, self-inquiry and critical-openness, which aim to improve their scholarship and analytical skills. Students are assessed on these five clusters of learning outcomes: knowledge and understanding, cognitive skills, functional work skills, personal and entrepreneurship skills, as well as ethics and professionalism, either through formative assessments such as quizzes, tests, and assignments, or summative assessment, in the form of final examinations.

\section{When Covid-19 Struck: A Chronology of Malaysian Higher Education's Response}

\section{January 2020: The Onset}

The first three COVID-19 cases in Malaysia were reported on 25 January 2020. HEIs in Malaysia were directly impacted by the 1 Statistics on the Malaysian higher education system can be accessed via https://www.mohe.gov.my/en/
download/awam/statistik 
COVID-19 crisis immediately, long before the rest of the country was put into lockdown on 18 March 2020, as they had to manage the inflow of international students for the February 2020 intake. They took the initiative to contain the risk of COVID-19 infection by mandating a 14day self-quarantine period for the students in designated residential facilities. They also issued travel advisories to academic staff to limit nonessential travel abroad, particularly to countries with reported cases of COVID-19 transmission, and also placed restrictions on meetings, mass gatherings, and sports and recreational activities. Classes were still conducted in lecture halls, and laboratory sessions proceeded as usual.

By 31 January 2020, the World Health Organisation (WHO) declared the coronavirus outbreak a global health emergency.

\section{March 2020: The Showdown}

This month marked the rapid downward spiral of the COVID-19 pandemic in Malaysia. The number of cases of COVID-19 transmission spiked to 428 cases by 15 March 2020 .

On the advice of the National Security Council (NSC), the government decided to postpone all mass gatherings including international meetings, sports, social and religious events. Universiti Sains Malaysia (USM) was the first public HEI to mandate all $\mathrm{T} \& \mathrm{~L}$ activities to be conducted online, and to restrict its faculties and offices to organizing only internal activities involving no more than 30 participants on campus (USM, 2020). Generally, the response by some HEIs was to encourage or mandate online learning, using live streaming (e.g., Facebook) or in-house e-learning platforms (Lim, 2020; Ramadan, 2020; Teoh, 2020; Universiti Malaysia Sarawak, 2020). Some HEIs, however, such as Universiti Utara Malaysia (UUM) and the International Islamic University Malaysia (UIAM) continued with their face-to-face lectures. Universiti Malaysia Perlis (UniMAP) students were not allowed to leave campus without permission (Lim, 2020).
On 16 March 2020, in response to the alarming increase of infections due to a mass religious pilgrimage and international inbound carriers, the Prime Minister of Malaysia announced the government's decision to implement MCO from 18 to 31 March 2020. Borders were closed, and inter-state air and land travels were prohibited. All educational institutions, businesses and premises were required to close, except for those offering essential services such as healthcare, and supermarkets. Mass gatherings were also banned, and everyone was required to stay home to minimise risk of infection.

The lack of knowledge about the virus, coupled with the speed of its spread, created a situation that was unprecedented in the Malaysian higher education system. On 17 March 2020, the Ministry of Higher Education (MoHE) issued a directive that students residing in hostels and dormitories provided by their respective institutions could choose to either return home before the start of $\mathrm{MCO}$, or to remain on campus throughout the lockdown period. The MoHE also took the unusual step to prohibit all digital learning activities on 17 March (Ministry of Higher Education 2020a; Asia Pacific University of Technology \& Innovation, 2020). Both public universities and private HEIs were forbidden to conduct any T \& $\mathrm{L}$ activities, including those online, as well as examinations, viva voce, student development and research activities during the restricted movement period (Asia Pacific University of Technology and Innovation, 2020).

Subsequently, media and public interest in how the MoHE and HEIs were managing the closure in terms of sending students home was excessive, mostly condemning universities for their lack of mitigation on the possible increased risk of infection during travel (Annuar, 2020; Adnan, 2020). The decision to send students home, or allow them to return home instead of staying on campus during the restricted movement order period was feared to have widened the circle of infections via the mass student movement. The delayed 
announcement, which was made on the eve of the MCO, was also criticised as it created panic and anxiety among parents, who had yet to make arrangements to bring their children home. This directive was eventually recalled on 20 March 2020, when the MoHE forbade students residing in hostels, dormitories and rented properties to leave the premises to return to their hometown or homeland during the duration of the $\mathrm{MCO}$ (Ministry of Higher Education, 2020b). Meals and sundry items for all students were supplied by their respective HEIs, paid for by a contingency fund provided by the government.

The Ministry also retracted its earlier suspension of $\mathrm{T} \& \mathrm{~L}$, allowing those HEIs that had been offering courses fully online to implement e-learning during the two weeks of MCO (March 18 to 31), provided that the institution could guarantee that every student had access to the Internet and that the lecturers were ready and fully equipped, with adequate infrastructure (Asia Pacific University of Technology \& Innovation, 2020, Ministry of Higher Education, 2020b). This decision was taken to ensure that the right to sustain educational activities for all registered, full-fee paying students in HEIs was protected within the framework of equal opportunity and nondiscrimination.

At this stage, all teaching, research and service activities, and administration came to a halt as the management grappled to respond to the MCO. Many students were left stranded in their universities and private accommodations. Those who were undergoing their internships and practicum were unsure of their status, in terms of continuity of their terms of service and its impact on the end-of-term assessment. It became clear that neither MoHE nor the HEIs were equipped with disaster and risk mitigation plans. This was not surprising, since Malaysia had never experienced any disastrous crisis prior to the pandemic. There was little understanding within the HEIs' and MoHE's organisational structures as to who was ultimately responsible for decision-making, and developing and implementing contingency plans. Throughout
18 to 31 March 2020, administrators at HEIs worked around the clock, putting together contingency measures for T \& L activities, as well as work arrangements for all staff in respective institutions. USM, for example, immediately carried out their scenario planning activities to devise changes during and after $\mathrm{MCO}$, and to help create national service initiatives such as the setting up of COVID-19 special fund, production of sanitizers and providing first aid and over the counter medication for their community (USM, 2020a). The university continued to produce Response and Readiness Plan for COVID-19 Pandemic and Other Infectious Diseases Outbreaks on April 1, 2020, which is a framework of action plans providing general guidance for preparedness, response and communication to mitigate against COVID-19 and other infectious disease outbreaks of public health emergencies (see Preparedness Plan for Infectious Diseases Outbreaks USM, 2020b).

On 25 March 2020, the Prime Minister made a nation-wide announcement to extend MCO by another two weeks, starting from 1 14 April 2020.

\section{April - May 2020: The Acclimatisation Period}

As the number of COVID-19 cases in Malaysia continued to increase, the MCO was further extended into the third phase from $15-28$ April 2020 , subsequently into the fourth phase from 29 April - 12 May 2020, and the fifth phase from 13 May - 9 June 2020.

By this stage, HEIs had been gradually equipped with the necessary policies and standard operating procedures (SOPs) to manage their operations. Some HEIs such as Universiti Teknologi Mara (UiTM) and Universiti Kebangsaan Malaysia (UKM) adjusted their mid-semester break to end of April and introduced a new academic calendar. Both suspended all T \& L activities for their students, while giving buffer time for academic staff to be ready for online instruction. Universiti Teknologi Malaysia (UTM) issued a circular that mandated online delivery of $\mathrm{T} \& \mathrm{~L}$ activities until 31 
December 2020, and introduced a 4-week buffer period for students and staff to complete the syllabus for the remaining academic semester. Many HEIs also introduced Standard Operating Procedures (SOPs) for online assessments and final examinations, scheduled to commence on June 2020. Clearer SOPs were also issued on working from home arrangements for all academic and administrative staff.

On 27 April 2020, after having been campus-bound for over a month, stranded students were allowed to return home under strict SOPs. The movement of students was carried out in stages through strict coordination between zones, involving the Royal Malaysian Police Force, and local authorities, with advisory from NSC and the Ministry of Health $(\mathrm{MoH})$. This operation was perhaps the largest controlled movement of students ever recorded in the country, and was completed by early June 2020. Each student was required to undergo health screening prior to the journey home, and was advised to undergo quarantine for 14 days upon arrival, either at designated quarantine centres, or at their respective homes. Students needing to travel from Peninsular Malaysia to East Malaysia and vice versa were transported via chartered flights from designated airports across the country. All transport expenses were borne by the government (Ministry of Higher Education, 2020c). Some students chose to stay on campus to complete their semester, with their meals and sundry items still being taken care of by the respective HEIs.

By this time, MoHE's directives and announcements had become better coordinated and evidence-based, given that it had had ample time to collect data on student demographics, as well as on ongoing $\mathrm{T} \& \mathrm{~L}$ activities from HEIs. A 24-hour COVID 19 operation centre was set up at its Putrajaya base, where parents, family members, and the community could seek information and advice (Ministry of Higher Education, 2020d). It announced a postponement of higher education intake for foundation, matriculation and diploma programmes to July/August 2020, while intakes for degree programmes would be delayed to September/October 2020 (Ministry of Higher Education, 2020e). All academic programmes were assumed to be conducted fully online as stipulated by all the HEIs in their websites and guidelines. There was greater clarity on the different forms of learning to be delivered remotely: classes could be conducted synchronously online, or asynchronously through recorded lectures and materials (UKM, 2020; UM, 2020). Academics were given alternative delivery modes: from a PowerPoint presentation with synchronized audio track, to a regularly monitored asynchronous, online discussion board for students to post messages; a discussion board that was monitored during a particular time-frame; and a chat session (Asia Pacific University of Technology \& Innovation, 2020; MultiMedia University (MMU), 2020).

Subsequently, capacity building of academic staff through webinars and guidelines was scaled fully online. It was also decided that summative assessments could be executed through various options, such as timed takehome examinations and proctored live sessions, subject to accreditation requirements from professional bodies. Universiti Kebangsaan Malaysia (UKM), for example, decided on redesigning exams (titled as final assessments) to fit within a set of various options open to lecturers - from a take-home exam paper (to be submitted via electronic means) to an online assessment (essays, multiple choice questions, or short answers) (UKM, 2020).

HEIs also introduced SOPs to manage work processes at the office including physical distancing measures, log in/out facilities, and personal protective equipment (PPE) such as face shields and face masks were procured or produced in-house not only for the university, but also for frontline workers in hospitals and within communities. Contingency funding to help students with broadband subscription and device procurement was also made available. HEIs were also required to report their plan of action on productivity recovery to the Public Services Department of Malaysia (PSD), with 
the expectation that up to 70 percent productivity could still be maintained throughout the MCO period by end of May 2020 (Public Service Department, Malaysia, 2020)

\section{June - August 2020: The New Normal}

With new infection rates dropping sharply in June, the Prime Minister introduced the Recovery MCO (10 June to 31 August 2020) on 7 June 2020. Throughout this RMCO period, more economic sectors were allowed to operate, and work would resume in HEIs, subject to stringent physical distancing measures required by $\mathrm{MoH}^{1}$. Nevertheless, online delivery of their academic programmes would still be required until the end of 2020 as stipulated by MoHE, with exceptions made for the following few categories of students:

1) Post-graduate students in research mode, i.e., those required to attend physical laboratories, workshops and design studios, or relying on specialised equipment to conduct their research;

2) Final-year students doing postgraduate studies, as well as Diploma and Bachelor Degree students required to carry out clinical work, practical, laboratory work, workshops, work in design studios, or are in need of specialised equipment, are allowed to have $\mathrm{T} \& \mathrm{~L}$ on their campuses, as early as July 1;

3) Final-year students who do not have internet access and are in an unconducive environment for $\mathrm{T} \& \mathrm{~L}$ via online are allowed to return to campus as early as July 1 , and utilize their on-campus infrastructure for the online $\mathrm{T} \& \mathrm{~L}$; and

4) Students with special needs enrolled in the Technical and Vocational Training (TVET) education programme at polytechnics and community colleges, and who need to get face-to-face guidance in order to access $\mathrm{T}$ $\&$ L due to learning difficulties (Ministry of Higher Education, 2020e).
The HEIs are also advised to implement staggered return of staff to campus for work, or allow their staff to work from home.

As the recovery MCO period is still ongoing, at the point of writing it is too early to comment on the effectiveness of HEIs' response throughout the crisis period. That said, it is argued that the period between April to May 2020 provided ample time for HEIs to prioritise their resources, and chart out their responses in a more coordinated manner.

\section{Managing Teaching and Learning Amidst COVID-19 Lockdown}

In the absence of references to similar crises in the past, it is difficult to analyse real evidence of impact and predict what may happen in the Malaysian higher education system in the immediate future. However, it is possible to document the current impacts on $\mathrm{T} \& \mathrm{~L}$ based on reports, personal experiences and anecdotes. In an effort to facilitate an analysis of successful actions and their accompanying challenges in the implementation of educational programmes in the HEIs, the real and estimated impacts of $\mathrm{T}$ $\& \mathrm{~L}$ are presented in this section, drawing from the experiences of three different stakeholders: students, academic staff, and the HEIs.

\section{Safeguarding Student Welfare}

At the start of the lockdown, it immediately became clear that the first priority for HEIs was to take care of the basic needs of students who remained on campus. Cafeterias and on-campus sundry stores were closed, and students were not allowed to venture outside the campus for meals and supplies. Student affairs divisions went into full operation, providing these essential services to students on campus. Headcounts were done to ascertain the number of students requiring meal assistance, and businesses were quick to provide in-kind donations to HEIs. Students were also notified of important contacts in case of emergencies, and of the availability of health

2 General statistics and infographics issued by the $\mathrm{MoH}$ can be obtained from http://covid-19.moh.gov.my/ 
services, counselling services, and campus security services throughout the MCO.

Students' mental and emotional health was also taken into account. Students reported feeling frustrated over the inability to move about with their peers, even within the campus compound. They expressed frustration over the uncertainty of the current situation in hand, as well as updates to their parents and family members back home. Like other students in the world, Malaysian students' anxiety and stress resulted from a number of issues including the need to quickly master new technology (to submit assignments and exams), concerns over not receiving the full range of face-to-face services and a lack of confidence in the new processes (Kerr, 2020, Wang \& Zhao, 2020). Some students raised concerns about the quality of their learning experience, and expressed worries over the accessibility of online repositories and paid software when working off campus. (Jalli, 2020). This is understandable as studies have shown that students have difficulties managing their learning online, as they tend to multi-task, check email, chat with friends, and surf the Internet while attending online lectures (Bao 2019; Bao \& Zhang 2018). Other common problems when being selfisolated at home are: poor self-discipline, lack of suitable learning materials, or an unconducive learning environment. Thus, online teaching implemented quickly during the COVID-19 outbreak was clearly a source of anxiety for the students (Regehr \& Goel, 2020; Cao et al., 2020), and their stress needed to be managed to ensure that they could actively and effectively engage in online learning (Bao, 2020).

Those who managed to return home before the lockdown began were worried about continuing with the academic semester, since their study materials were left on campus. In this instance, peer support, in the form of academic advisory services, residential college fellowships, and in-residence student networks provided emotional support to students, regardless of their location. HEIs also advised academic staff to be accessible to their charges, becoming the first line of responders on behalf of the institutions.

\section{Bridging the Digital Divide}

Students and staff require the following hardware in order to attend/conduct classes and assessments online: a working Internet connection; a digital device; and accessories such as headphones, speakers, and printers. Under normal circumstances, they would rely on in-campus facilities at libraries, centres for $\mathrm{T} \& \mathrm{~L}$, as well as centres for information and communication technologies to manage their tasks. However, access to these supportive learning spaces were abruptly cut off when Malaysia went into lockdown in March 2020.

Research reports and commentaries by various media have highlighted the issues experienced by students mainly in rural localities, such as those in Sabah and Sarawak and in remote areas in Peninsular Malaysia, who do not have access to high-speed internet connection to attend online learning sessions (Sani, 2020a; Rachel, 2020; Muhammad, 2020). Inevitably, socio-economic and regional factors play a pivotal role in accessing and affording online platforms (Palvia et al., 2018; Hawati \& Jarud, 2020). Some students in the B40 groups, defined as those who come from households with a monthly income of less than RM 3,000 (or USD 750), have no hardware, gadgets and devices such as desktop or laptop computer, nor a broadband Internet subscription (Hawati \& Jarud, 2020)

Although the Malaysian Communication and Multimedia Commission (MCMC) in 2019 reported that the national mobile broadband penetration rate was exceedingly high (120 percent per 100 people), the fixed broadband penetration rate which provides faster and more reliable connectivity was significantly low (approximately 8 percent per 100 people) (MCMC, 2020). Infrastructural shortcomings, such as the lack of fibre optic networks have been cited as the cause of slow internet speed undermining broadband connectivity in the country (Muhammad, 2020; Azmi, 2019). In 
2018, the Malaysian government pledged the provision of an average speed of 30 MBPS in 98 per cent of populated areas by 2023. This target is comparatively low for a country committed to driving digital economy in the future. The Canadian radio-television and telecommunications commission, for example, has aimed for a minimum speed target of 50 MBPS download services by 2020 (Azmi, 2019).

It is also interesting to note a juxtaposition between broadband penetration and quality of broadband services rendered to the Malaysian community. A study by the MCMC revealed that the percentage of internet users in Malaysia stood at 87 per cent or 28.7 million users in 2019. The World Bank's digital adoption index (DAI) painted an even more optimistic picture for the country, as the total number of mobile internet users is on par, if not surpassing its neighbours and other advanced economies (Azmi, 2019). However, its fixed broadband services only stood at 46 percent in 2018, significantly lower than that experienced in the EU, which recorded 95 percent fixed broadband penetration. Although Malaysia's digital adoption rate is comparable to advanced economies, the actual digital adoption is that of a lower middle-income country, with more than 50 percent of respondents citing poor quality and unaffordability as reasons for not taking up fixed broadband access (Azmi, 2019; Muhammad, 2020).

Socio-economic and regional factors play pivotal roles in accessing and affording online platforms. Findings from a survey by the Ministry of Education (MoE), involving close to 900,000 school students indicate that 37 per cent of school students do not have any appropriate electronic devices for learning (Ministry of Education, 2019). At the same time, only 6 to 9 per cent of students own a personal computer and/or a tablet. This is a stark contrast to 78 per cent of households in America that own a desktop or laptop computer, and 74 per cent who have a broadband internet subscription. Some students in the B40 groups, have no means of owning the hardware, gadgets and devices such as a desktop or laptop computer. Students in rural localities and remote areas across the country do not have access to high-speed internet connection to attend learning sessions online. Digital infrastructure, internet speed, network access, and affordability pose real obstacles to the equality of online education. Like many other developing countries, a larger number of Malaysian students than anticipated do not have reliable access to internet and useful devices for online T \& L (World Bank, 2016; UNESCO, 2020). UNESCO recently noted that school closures in Asia due to COVID-19 have put millions of children falling behind in education as classes shift online (UNESCO, 2020). It seems that remote learning is still a luxury largely accessible to the elite and middleclass students from cities and towns with good broadband access, side-lining participation of the socio-economically disadvantaged students outside these areas.

Academic staff were also affected by the digital divide. Besides optimal broadband connection, an academic staff may require digital devices with enhanced capabilities to record lectures and administer learning and supervision sessions, either in synchronous or asynchronous modes. A basic home studio, for example, requires a webcam, microphones, appropriate lighting and audio modulation equipment. Round-the-clock technical support is also required for managing unforeseen glitches. Furthermore, interactivity in online instruction requires the subscription of applications and online platforms, which may incur out-of-pocket expenses from the individual academic staff.

Clearly, hardware and software issues must be addressed before remote learning can successfully take off. Quality online delivery requires high-input operations, requiring time to develop and significant investments to run (Gyukkal, 2020; Kim, 2020; Shattuck, 2014). While digital technologies can be deployed at scale, much more needs to be done on the hardware side in terms of bandwidth capacity and digital inequalities. Thus, the digital divide that still exists in Malaysia posed the greatest 
challenge to online $\mathrm{T} \& \mathrm{~L}$ for all students. The COVID-19 pandemic has exposed this starkly and it should become the government's most crucial infrastructure to prioritise.

\section{Academic Staff Capabilities}

As the COVID-19 pandemic has caused such a dramatic acceleration of online university distance education, the signal being sent to the academics during the COVID-19 crisis was clear: online distance education was the only viable tool to sustain academic activities and it had to be immediately employed. Arguably, most academics share their HEI's leadership's sentiments that the COVID-19 crisis has brought forward the inevitable digital platform by a full generation. Resorting to online T \& L was clearly a breakthrough, and an impactful consequence of an otherwise disastrous global health crisis.

It requires deliberate planning and practice to transfer content for online delivery, with an average of six months to one year of development time for a fully online university course (Roddy, et $a l ., 2017)$. As experienced by many academic staff throughout the MCO period, transferring content online takes time, and requires extra work. The extra workload experienced by the academic staff was generated by the need to rewrite materials and to reorganize assessment tasks, the videotaping of lectures, additional effort associated with reformulating formative and summative assessments, as well as assessing electronically submitted assignments and tests. It was an uphill battle for every academic staff to pivot online within a short period of time, and virtually impossible for every faculty member to suddenly become an expert in online $\mathrm{T} \& \mathrm{~L}$ under such tense conditions, within a few weeks of the directives. Academics usually become more comfortable teaching online by the second or third iteration of their online courses. While resources are available to turn to for assistance, the scale of change that stresses the systems providing those resources most likely would surpass their capacities. It is argued that many of the online learning experiences offered throughout the MCO period may not have been fully featured or necessarily well-planned, with a high probability of suboptimal implementation with simple online content delivery and activities.

A number of lecturers have expressed scepticism about maintaining quality in online course delivery (Mustafa, 2020). This perception was reinforced by students who frequently expressed disappointment that they were not receiving 'value for money' because of the reduced face-to-face component of the course delivery (Sani, 2020b; Jalli, 2020). A few academics reported grave concerns in the media about the quality of work submitted by some students, and a few others worried that standards might be compromised by the new assessment arrangements (for example, takehome and open-book exams) (Mustafa, 2020). Evaluating students' learning acquired through distance learning has remained a challenge for quality assurance (Gaskell \& Mills, 2014).

Students, parents, and the general public have also been unsettled about the quality of online education during the pandemic (Daniel, 2020). Students are not confident that their learning experience online is even on par with, let alone better than, face-to-face instruction, and feel they are not receiving value for money in their education investment. For now, the quality dimensions of online education related to the academic staff encompass the following areas: competencies of academic staff tasked to deliver learning online; the quality of online formative and summative assessments; and the ability of academic staff to assess novelty and authenticity of work submitted by the students (Antony \& Gnanam, 2004). These quality dimensions would, in the medium- and long term, compromise quality assurance of academic programmes, subsequently affecting students' outcomes of higher education. It is highly unlikely that these issues will be resolved under the present circumstances. 


\section{HEI Capabilities}

The COVID- 19 pandemic revealed one possible breakthrough that could be introduced into core functions of the sector, which has been highly resistant to change for the longest time. By the second phase of the MCO, many HEIs had adapted policies and guidelines to enable remote working and learning from home for their communities, and had also made revisions to the academic regulations and calendar to ensure continuity of teaching, learning, and research activities. Oral examinations for postgraduate students, meetings, and interviews that were commonly organised physically, were pivoted online, saving travel time and reducing carbon footprints of academics and administrators (Versteijlen et al., 2017). Automation of work processes, through online platforms and systems, reduce turnaround time for routine processes in academic administration. Malaysian HEIs have also shown solidarity, cooperation, and resilience in their responses, by collaborating with other HEIs, organisations and civil societies to introduce various initiatives to reduce the impact of the pandemic in their communities, such as producing Personal Protective Equipment (PPE) for healthcare workers through the use of $3 \mathrm{D}$ printers in laboratories across HEIs (Chong, 2020).

A key element for structured online delivery is the use of a learning management system (LMS) in order to organise learning for both students and staff. HEIs may opt for opensource platforms, such as Moodle, to deliver their programmes online. These platforms require time to master; UTM, for example, took more than 10 years to develop the technical capabilities and expertise in optimizing Moodle as a credible LMS for T \& L. An advanced LMS such as Blackboard may provide technical support to students and staff, but requires subscriptions and annual renewals. Smallscale and newly established HEIs may not have an adequately effective infrastructure and investment capital to implement a full online delivery. As a result, their students may not experience optimal learning for the remaining of the academic year.

A summary describing the chronology of events and the government's decisions plus responses from the MoHE and the HEIs throughout the COVID-19 MCO period are shown in Table 2. 


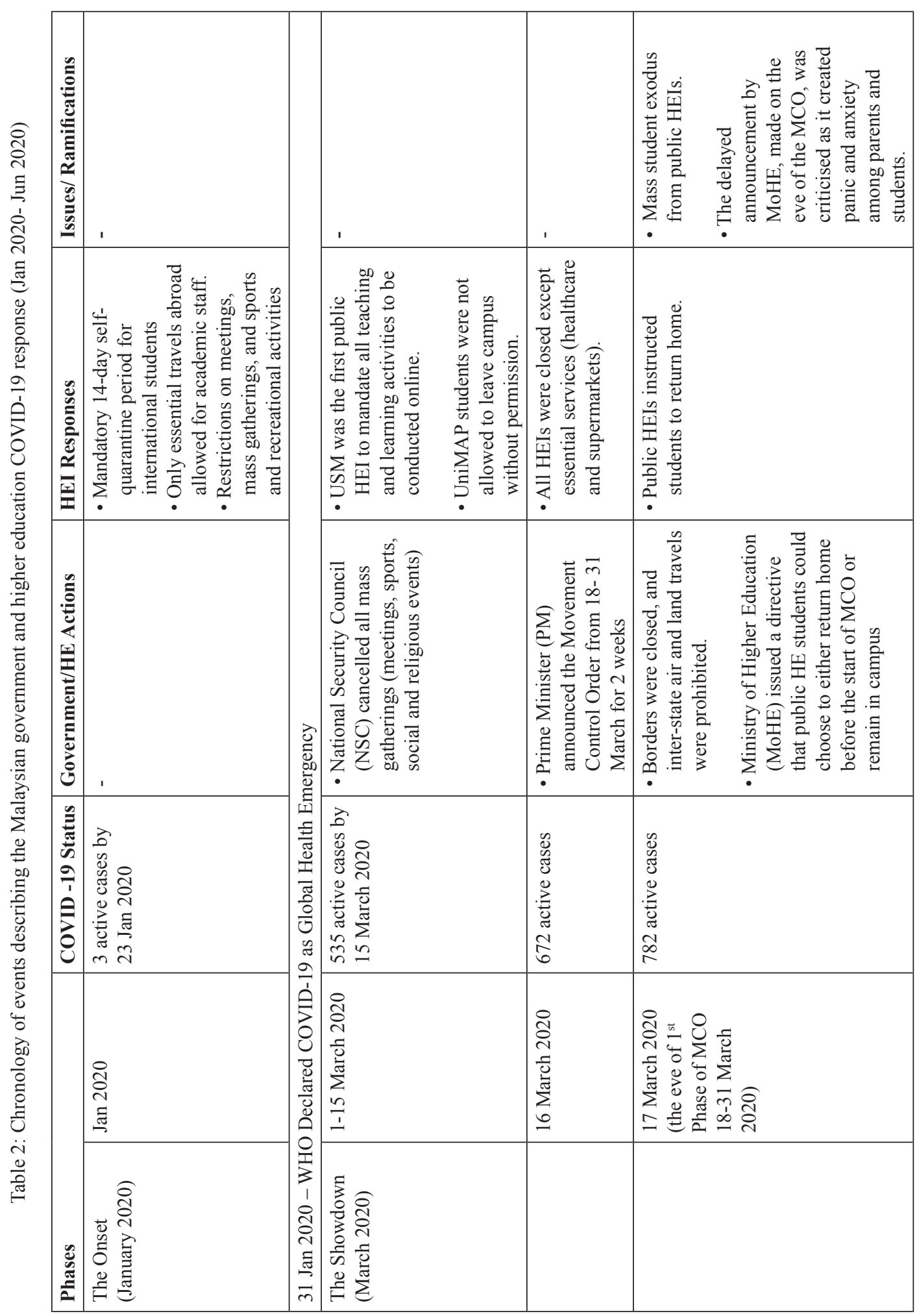

Journal of Sustainability Science and Management Volume 16 Number 1, January 2021: 70-96 


\begin{tabular}{|c|c|c|c|c|c|}
\hline \multicolumn{3}{|l|}{ 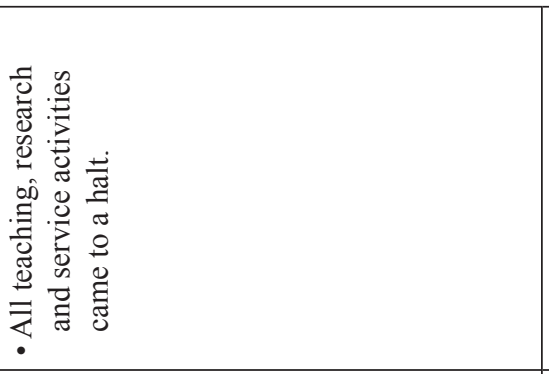 } & ' & \multicolumn{2}{|c|}{ 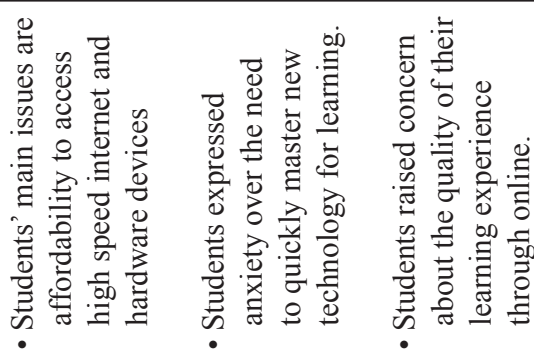 } \\
\hline 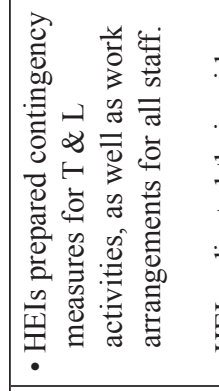 & 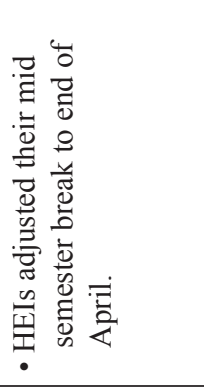 & & 1 & 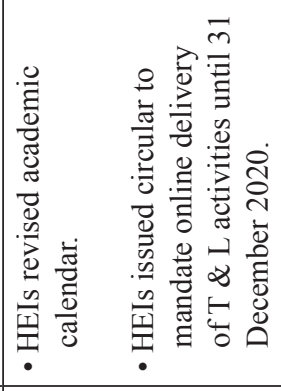 & 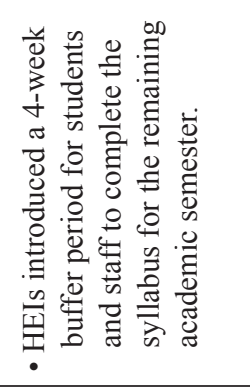 \\
\hline 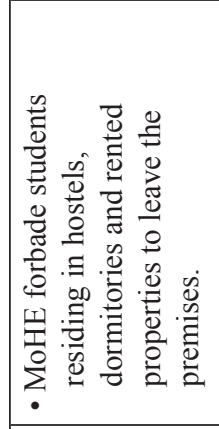 & 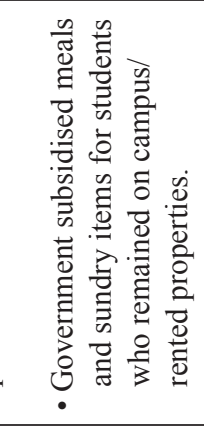 & 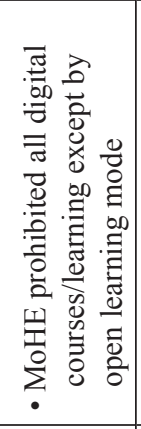 & 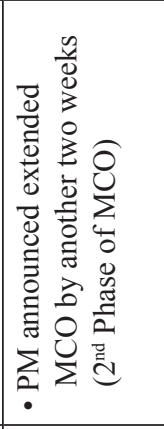 & & \\
\hline 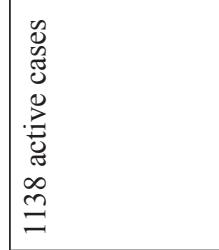 & & & 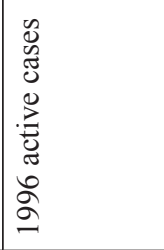 & 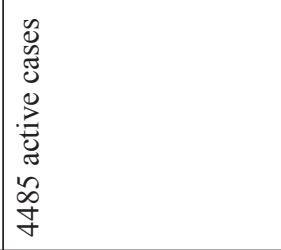 & \\
\hline 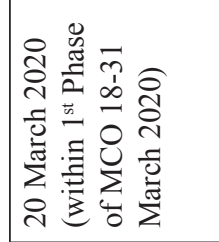 & & & 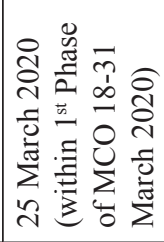 & 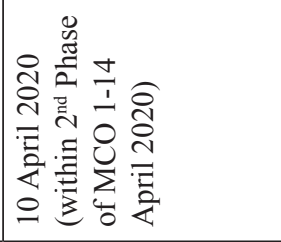 & \\
\hline & & & & 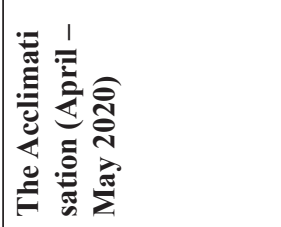 & \\
\hline
\end{tabular}




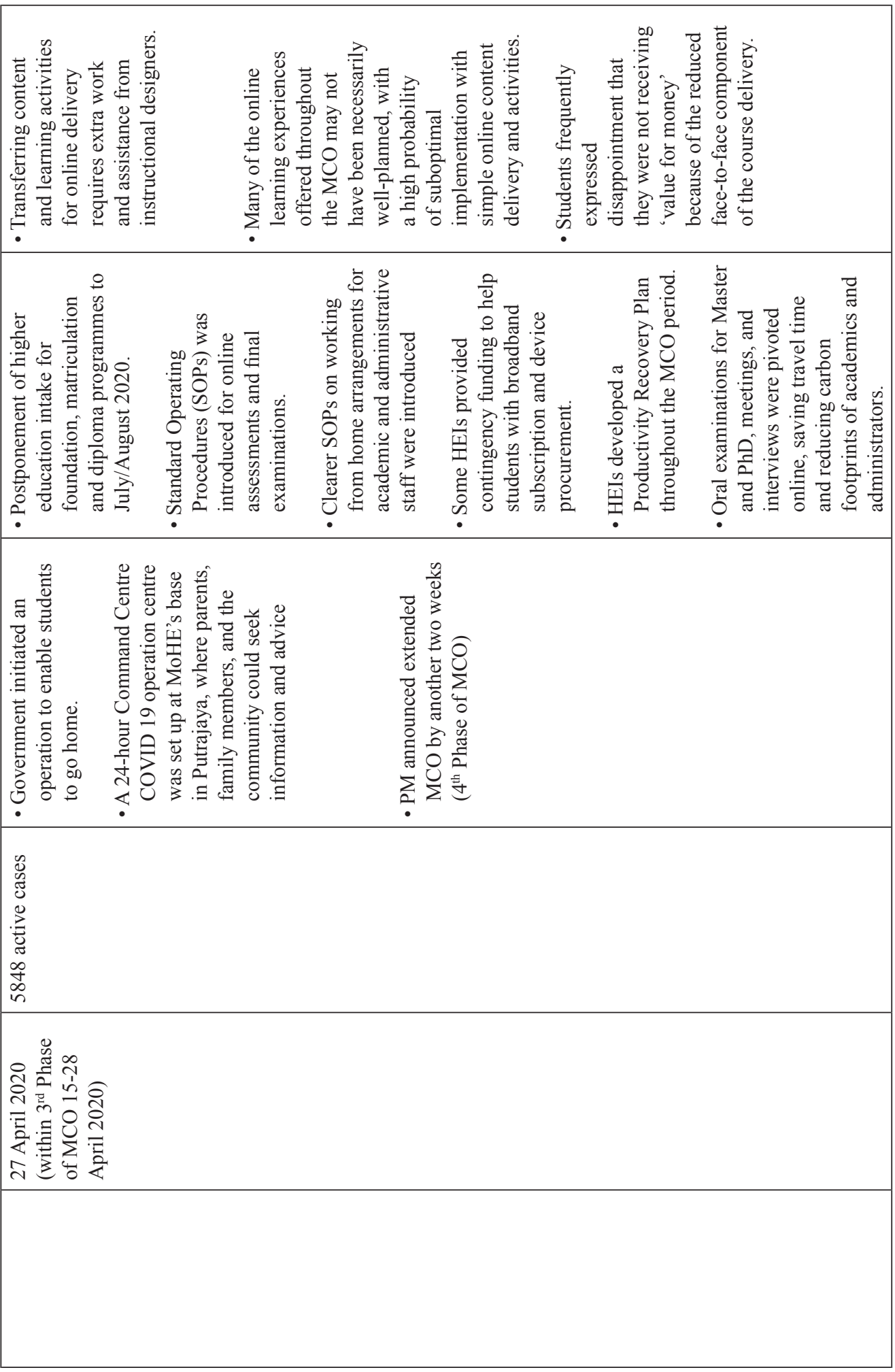




\begin{tabular}{|c|c|c|}
\hline \multirow[t]{2}{*}{ ' } & י & \\
\hline & 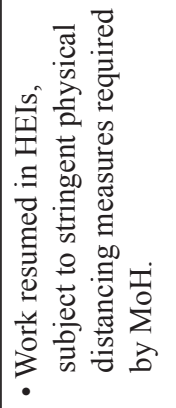 & 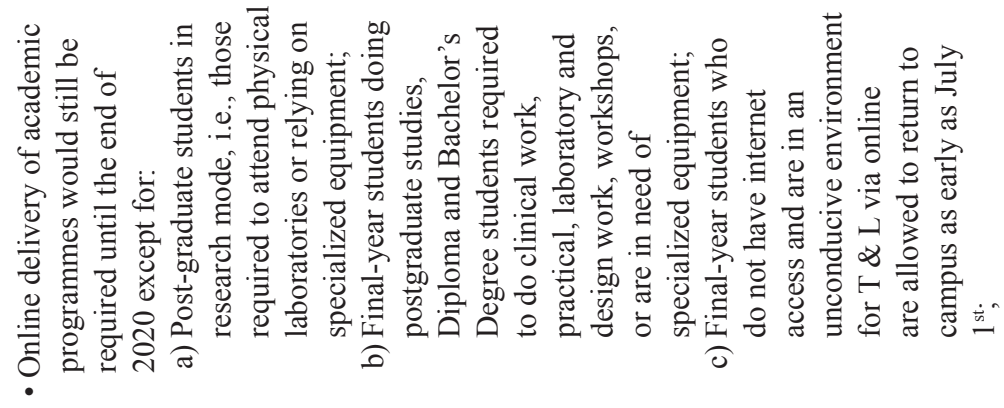 \\
\hline 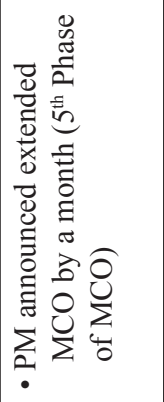 & 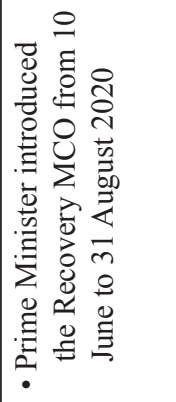 & \\
\hline 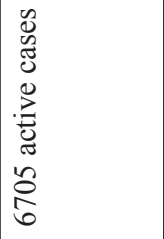 & $\begin{array}{l}0 \\
0 \\
0 \\
0 \\
0 \\
0 \\
.0 \\
0 \\
0 \\
0 \\
0 \\
\tilde{J} \\
\infty\end{array}$ & \\
\hline \multirow[t]{2}{*}{ 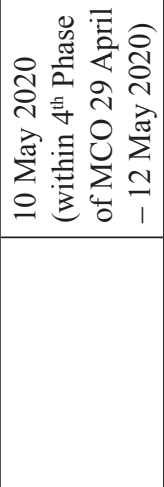 } & 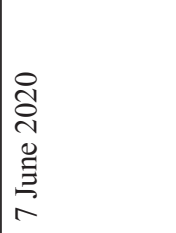 & \\
\hline & 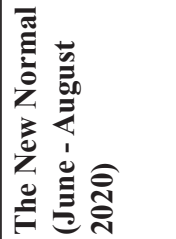 & \\
\hline
\end{tabular}




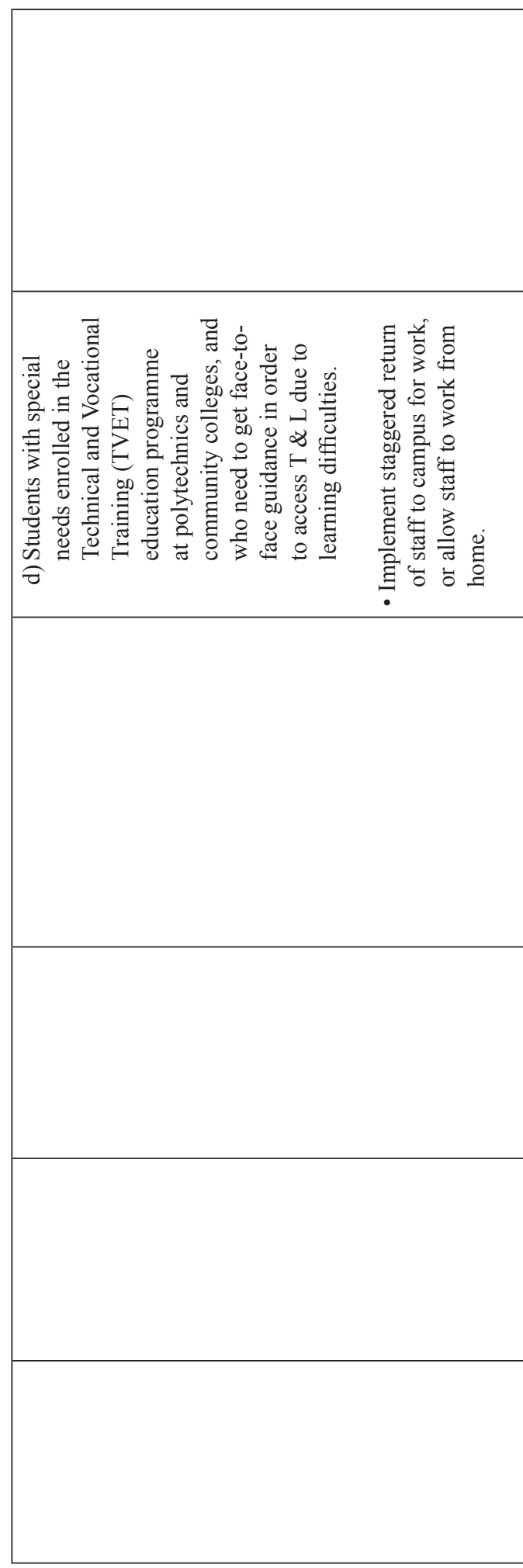

Lessons Learnt and Implications for Practice

Higher Education Leadership is Essential for Weathering the Storm

Many HEI leaders would likely have embraced the importance of disruptions such as those caused by economic recession, industrial revolution and artificial intelligence (Gigliotti, 2016; McGee, 2015). These forward-looking leaders have so far embraced these disruptions to refocus and advance their HEIs by creating prudent changes to their core functions and operations. Some leaders create guardrails and safety precautions to build institutional agility during the transformation process (Jameson, 2012). The guardrails and safety precautions for higher education are supported by a number of mindsets and academic values including systems thinking (HEIs are interconnected), culture of excellence (commitment to long term gain and quality) and sustainability. However, the COVID-19 disruption is of a different nature altogether as there are no guardrails available nor can humans control the pace.

Aligned, visionary leadership takes different forms, but each leader must be sensitive to the unique institutional contexts in making decisions. Thus, the leaders of HEIs, as autonomous institutions, are expected to respond based on what works best for their respective institutions, rather than wait for MoHE to issue guidelines and directives. HEIs must continue to sustain their mission of education to students, support their faculty and staff, fulfil duties as partners in the communities, and to produce solutions to national problems created by the ripple effect of COVID-19. HEIs should collect verifiable evidence, evaluate it rigorously, and apply independent critical thinking to solve other issues related to COVID-19.

The COVID-19 has thrust the higher education system into an e-learning experiment of an unprecedented scale and scope. It is important for leadership to recognise the professional burden suddenly thrust on faculty and staff during a personally stressful time, and therefore set more reasonable, realistic expectations. The 
way HEIs transform all of their instruction in this compressed time frame will result in a pale imitation of what quality online instruction is, and exposing the entire academic staff and students to this trial product will likely cause setbacks; instigating apprehensiveness rather than instilling positive attitudes in faculty and student to technology-enabled learning. Thus, it will be important for the management to collect data on students' learning experiences and the academics' experience in remote $\mathrm{T} \& \mathrm{~L}$ using technology, and to use the feedback to improve on contingency plans, and to plan for preparing students and facilitators for engaging in online $\mathrm{T} \& \mathrm{~L}$ should HEIs ever have to close due to any crisis in the future. Additionally, there is a need to conduct a rapid technology assessment (identifying weaknesses in infrastructure, including power, broadband and equipment to strengthen delivery), and produce an estimate of the costs to sustain continued remote $\mathrm{T}$ \& L (including infrastructure/equipment, connectivity, etc.) to the end of the year.

\section{Students at the Heart of Education}

Students' welfare must be a priority at all times. It is pivotal to address their learning loss throughout the $\mathrm{MCO}$, and to provide special assistance to the underprepared and the less privileged to enable greater access to higher education. Generally, the primary concerns of the HEIs in the immediate and long term should be about the impact of the pandemic on all students, while paying specific attention to the low-income and underrepresented students (Weissman, 2020; Zhong, 2020). This is because, even in normal circumstances, those students are most vulnerable to having their education derailed, and their personal wellbeing threatened.

As described in the preceding section, COVID-19 has exacerbated the existing inequality among students, particularly in terms of their access to the Internet, the inadequacy of appropriate devices for T \& L, and students' mental health and emotional well-being, among others. It is also important to restore the safety and security normally experienced on-campus, through the provision of safe online and offline learning spaces, so that the students are able to resume and complete their studies as soon as possible. The key takeaway is that narrowing the digital divide is not about improving access to places, but to people.

\section{A Blended Approach in Learning}

The COVID-19 pandemic has enhanced appreciation for conventional face-to-face learning, and the traditional campus classroom (Mustafa, 2020; Mahesh, 2020). Generations of parents have chosen to spend money on having their children educated at the best schools and universities, sometimes hundreds or thousands of miles away so that their children can access the best professors, classrooms and libraries in person. For the majority of students, going to college is considered as a rite of passage and a transformational personal journey (Blumenkrantz \& Goldstein, 2014; Tinto, 2011). Even if academic course work can be replicated online, what cannot be replicated is the organised supporting ecosystem, such as extracurricular activities and team work, which are crucial components of a traditional higher education (Mannan, 2007; Jorgenson, et al., 2018). These activities create social capital, prepare students for civic engagement and combat the self-absorbed individualism which undermines democratic society (Resnick, 2000, Flores \& Rogers, 2019). The reality is that the digital classroom can never displace the traditional campus classroom. Those who seek the conventional face-to-face university teaching experience will continue to seek out HEIs that provide those experiences.

During the global lockdown, academics do the best they can, trying to take just the essentials with them as they rush to develop materials for online delivery, managing with bare minimum resources and competencies to deliver meaningful learning experiences. It bears reminding to distinguish between the normal, everyday type of effective online instruction and that which is prepared in a hurry or during 
an emergency. HEIs should emerge from the global health crisis with a much more widely shared understanding that digital tools are complements, not substitutes, for the intimacy and immediacy of face-to-face learning. Faceto-face lectures and tutorials are only part of an overall T \& L ecosystem that should specifically be designed to support learners with formal, informal, and social resources. Online tools can be used effectively for structuring content, while precious classroom time can be more productively utilised for stimulating discussions, debates, experiential learning, and hands-on skills development (Mustapha, 2020; Ananga \& Biney, 2017; Saghafi et al., 2014). Ultimately, effective education delivered online requires an investment in developing an ecosystem of learner support, which also takes time to identify and build.

Globally, online and distance education is a well-established domain of study within the education technology segment. Greater quality empirical studies are required for the Malaysian context (Kumar \& Al Samarraie, 2018) as most comparative research on online learning and classroom interaction has been plagued with a variety of methodological problems and confounders that make the results unreliable (Abrami et al., 2011). Generally, there is a confusing and inconclusive response to the overall question of effectiveness of online teaching vs the face-to-face method reported in the literature (Wagner et al., 2010; Kemp \& Grieve, 2014; Paul \& Jefferson, 2019). Moreover, scholars claim that online learning research and development is still in its infancy with regard to facilitators' ability to engineer successful interaction among students, between teachers and students and between students and content (Paul \& Jefferson, 2019).

While the "experiment" in full online learning is in process, Malaysian HEIs must investigate which classes are benefiting from being taught remotely, and which are not. Data on technology issues, course design, course delivery, and evaluation methods must also be collected. Such data can then inform future decisions about when and why some courses should be taught remotely or online, which ones should remain on campus, and which within-campus classes should be supplemented or complemented by technology. Currently, HEIs are using trial-and-error approach with their fully online courses, as well as their LMS. Both academics and students are readjusting and recalibrating in the middle of teaching semesters, with the syllabus and course content being revised, particularly on the requirements of doing practical sessions, internship, experiential learning as well as assessment methods. It is hypothesized that as the novelty of full online classes in a crisis situation wears off, boredom and apathy could set in. Full online learning will be no more attractive than the traditional classroom setting. Thus, empirical research on these issues will provide directions for how to train future virtual educators and learners.

\section{Rethinking Flexible Education}

In April 2018, MoHE published "Framing Malaysian Higher Education 4.0: Future-Proof Talents", a document that outlined the Ministry's aspiration in redesigning higher education for the country. At the system level, MoHE introduced the concept of Higher Education 4.0, where students are envisioned as curators of knowledge, content producers, and connectionmakers, the web as the open global curriculum, and educators as the resource guide. For the HEIs, it outlined a four-quad future university mode, recommending HEIs to be adaptive, flexible, and to offer lifelong learning pathways for individuals through nano- or micro- certification programmes, which are stackable and industrydriven. It also encouraged HEIs to adopt a fluid and organic curriculum approach which allows convergence of disciplinary content areas, implementation of gap year and inter-university collaborations, as well as promoting access to education anytime, anywhere. Finally, for the instructors and the academic fraternity, MoHE encouraged them to embrace $21^{\text {st }}$ century modes of instruction, such as heutagogy (studentdirected learning), paragogy (peer-supported 
learning), and cybergogy (virtual learning experiences) (Ministry of Higher Education, 2018).

Evidently, it takes a global pandemic to drive home the message that Higher Education 4.0 is a concept ripe for implementation in a post COVID-19 world. Despite the calls from MoHE to make academic curriculum fluid and organic, it is clear that the HEIs have been slow in responding to the call. The fear of the unknown might have been the leading cause of resistance from the HEIs. Gradual scaling-up of existing programmes, and piloting initiatives at a sample of HEIs are feasible options, compared to a blanket implementation across all HEIs. Clarity should be given to all stakeholders in terms of the impact of Higher Education 4.0 on student outcomes and accreditation status of academic programmes. It would also be appropriate for MoHE to provide incentives for HEIs and industry players to champion the initiatives, particularly in terms of training programmes and targeted investments for students and staff. Finally, one should never underestimate the wisdom of the crowd; by empowering individual academic staff and HEIs to drive change, and letting students experiment on their own, Higher Education 4.0 will be a feasible concept in Malaysia, rather than being just a beautifully written plan on paper.

\section{Evidence-Based Policymaking}

Most academics share their leaders' sentiments that COVID-19 has accelerated digital transformation in higher education by a full generation. Malaysia is an early adopter in the provision of online and blended learning, having introduced in 2011 a national policy on online learning, and a subsequent revision of the policy in 2017. Additionally, the country also has wellestablished HEIs that have been delivering education through online and distance learning for more than 40 years, such as Open University Malaysia (OUM), Asia e-University, and Wawasan Open University (WOU), among others.

Despite the advances in policy formulation, adaptation at the HEI level has been sluggish, as clearly evident throughout the lockdown period. Higher education leaders have come to realise that a switch to a full virtual platform requires a comprehensive understanding of the infrastructure and technological capabilities necessary to drive the transformation process. To date, information on the readiness of students and staff for online delivery is not readily available. Thus far, only a handful of institutional wide research reports can be found on students' capacity to engage in remote learning in terms of equipment, financial ability, family responsibilities, home environment, etc., revealing how realistic it is for students to adapt to facilitators' plans for delivery, and for facilitators to adapt teaching according to student capacity to participate in distance learning.

So far, informal feedback from different stakeholders reported in the media paint a grim picture at the implementation level (Rafidi, 2020; Jalli, 2020; Sani, 2020a, 2020b; Mustafa, 2020). As such, it is argued that the Ministry should spearhead data collection initiatives in order to understand the size and scope of the digital divide in HEIs and among students. This can be done potentially through a survey of system requirements, so that the resulting policies introduced can be better strategized and implemented.

If there is one single lesson for Malaysia to reflect upon, it is the Massive Open Online Courses (MOOC) platform initiated by MoHE in 2015. Heralded as an evolutionary innovation in online education, MOOC was the pet project of the Ministry, and its application was mandated in all public HEIs. Experts and policy makers lauded it and predicted that MOOCs would replace traditional higher education. However, while studies on MOOCs' effectiveness in Malaysia are limited and scanty, the global literature on MOOCs effectiveness in accommodating different students' abilities and needs show conflicting results. Specifically, global research on MOOC has highlighted that MOOCs struggled with student retention and completion. A study by the Massachusetts 
Institute of Technology (MIT) found that MOOCs had an astronomical dropout rate of about 96 per cent on average over five years (Reich \& Ruiperez, 2019). The longitudinal study on learners who registered for a course by MIT and Harvard on their joint learning platform (edX) also found that the dropout figure had not improved between 2013 to 2018. Fortunately, despite the MOOC phenomenon and disruption that threatened the traditional academic course methods, the Malaysian HEIs have sustained the test of time. The question remains whether it is best for students to return to the classroom when the COVID-19 crisis subsides and continue with the status quo, or if HEIs can find a better sustainable alternative to educate the future workforce of Malaysia.

\section{Conclusion}

This paper describes events that have happened (over the past three months) in relation to the disruptions caused by COVID-19 to Malaysia's higher education system, in the context of teaching and learning. Despite all the challenges, the response from the Malaysian HEIs during the period of uncertainty and contestation may be considered as good. The learning curve was steep at the start, but HEIs were quick to adapt, and it is argued that they have managed, endured, and were changed by the global pandemic.

While providing emergency aid to students and support for institutions, the MoHE, together with HEIs worked on the administrative measures to safeguard the educational delivery of programmes via remote online learning. The emergency adoption of remote learning will inevitably speed up the adoption and embrace of online and other forms of technology-enabled learning. Nevertheless, the main findings have highlighted that the digital divide still exists in Malaysia, and that it poses the greatest challenge to Malaysia's recovery post COVID-19.

The COVID-19 pandemic shows that ensuring the right to higher education for all within a framework of equal opportunity and non-discrimination is still a relevant goal to achieve under Goal 4 of United Nation's
Sustainable Development Goals (SDGs). In a post COVID-19 era, risks associated with crowded spaces, as well as distancing measures imposed by governments necessitate educators to deliver education online, and from a distance. For this to happen, each student must have access to digital learning device with learning applications and stable Internet connection. The publicness of education, in particular higher education, was highlighted significantly when students still encounter issues in accessing the very basic of devices and Internet connection for learning. Thus, it is imperative to address, as a priority, the pedagogical, economic, and socioemotional needs of vulnerable students - those who, due to their personal or socio-economic characteristics, may have had, or are having, greater difficulties in continuing their education in non-traditional modalities. Public higher education financing should not be considered as a cost, but an investment in empowering young people in building healthy, equal, inclusive and sustainable societies. While student outcome in terms of career-related skills and credentials are still relevant, these cannot be achieved if students do not have access to education in the first place.

Three issues were beyond the scope of this review, which need to be briefly described here. The first area is the pricing of tuition fees payable amidst the global pandemic. Since all classes were pivoted online, should the tuition fees be cheaper than lessons delivered faceto-face? Students were unable to use physical facilities such as libraries, sports centres, and lecture halls throughout lockdown - can they demand refund from their HEIs? The heated debate over this issue for the past few weeks, unfortunately, turned into a politically charged discussion. Moving forward, HEIs may have to confront the inevitable discussion on students' right to sustain educational activities, and they would need to ensure that students are protected within the framework of equal opportunity and non-discrimination.

The second issue is work from home arrangements for the academic staff, and its impact on $\mathrm{T} \& \mathrm{~L}$. Academics have been 
accustomed to working beyond the office, and are capable of delivering their best regardless of their location of work. When the lockdown was enforced, they had to juggle between work and family matters; some needed to carry out additional responsibilities as academic administrators. This may have bridged the gender gap in academia, but the additional workload could have affected the quality of work, which may consequently cause them to fall behind in promotion and career progression.

The third issue relates to international students. Malaysia exports its education services globally, and has been host to international students for the past thirty years. While major host countries such as Australia, the UK, and the US are worried about the flow of international students for the next two to three years, Malaysia's stand with regard to its education export remains unclear. At the point of writing, the borders are still closed to non-nationals. It is also unclear if the country would extend assistance, in the form of housing stipends, student pass extension, and cost of living expenses to international students who are still in the country. Looking ahead, should Malaysia intend to maintain its student hub status, it has to be seen as supportive and committed in the pastoral care of international students, and the sustainability of export education for the country, in particular the private higher education segment.

COVID-19 has caused dramatic acceleration of online university education. As we argued earlier, the digital classroom will never fully displace the traditional campus classroom. In thinking about the future and sustainability of the educational programmes, it is pivotal that every stakeholder refers to the national education philosophy of an integrated, balanced and holistic development of students. As stated in our National Education Philosophy, Malaysia's aim is to produce intellectually, physically, emotionally and spiritually balanced and harmonious individuals who will then contribute to the harmony and betterment of the family, society and the nation at large. Some learning experiences for physical, emotional and spiritual development cannot be replicated digitally. All Malaysian HEIs have the social obligation to provide a holistic educational experience for both students and staff through a social, emotional and physical context of T \& L.

On the strength of having had an excellent survival record over the centuries and phases of economic revolutions, some may predict a strong probability that HEIs will be able to handle the challenges of COVID-19 in T \& L, and to sustain the further growth of a knowledge society. Indeed, it would be nice to end this narrative on a positive note, but the COVID-19 experience should make us seriously more cautious about taking things for granted.

\section{Acknowledgements}

The author(s) extend their gratitude to reviewers for critical comments on the manuscript.

\section{References}

Abrami, P.C., Bernard, R.M., Bures, E.M., Borokhovski, E., \& Tamim, R.M. (2011). Interaction in distance education and online learning: Using evidence and theory to improve practice. Journal of Computing in Higher Education, 23(2-3), 82-103.

Adnan, S. (2020). COVID-19: Pentadbir universiti dibidas biar pelajar pulang ke kampung. Retrieved from https:// ww w. bharian.com.my/berita/ nasional/2020/03/666504/covid-19pentadbir-universiti-dibidas-biar-pelajarpulang-ke-kampung.

Ananga, P. \& Biney, I.K. (2018). Comparing face-to-face and online teaching and learning in higher education. MIER Journal of Educational Studies, Trends \& Practices, 7(2), 165-179.

Annuar, A. (2020). Sending university students home could increase risk of infection, observes ex UM director. Retrieved from https://www.malaymail.com/news/ malaysia/2020/03/18/sending-uni-studentshome-could-increase-risk-of-infectionobserves-ex-umd/ 1847733. 
Antony, S. \& Gnanam, A. (2004). Quality assurance in distance education: The challenges to be addressed. Higher education, 47(2), 143-160.

Asia Pacific University of Technology \& Innovation. (2020). COVID-19 updates \& advisory. Retrieved from http://www.apu. edu.my/ COVID-19-updates-advisory .

Azmi, D. (2019). Telco deep dive 2018: Digital divide in Malaysia leaves much more work to be done. Retrieved from https://www. digitalnewsasia.com/digital-economy/ telco-deep-dive-2018-d.

Bao, W. \& Zhang, X. (2012). The multidimensional structure and influence mechanism of student academic involvement in China. Fudan Education Forum, 6, 20-28.

Bao, W. (2019). Bridging the gap between research and practice: Identifying highimpact educational practices for Chinese undergraduate education. Peking University Education Review, 1, 105-129.

Bao, W. (2020). COVID-19 and online teaching in higher education: A case study of Peking University. Human Behavior and Emerging Technologies, 2, 113-115.

Baumeister, R. F., \& Leary, M. R. (1997). Writing narrative literature reviews. Review of General Psychology, 1(3), 311-320.

Bernard, R.M., Abrami, P.C., Borokhovski, E., Wade, C.A., Tamim, R.M., Surkes, M.A., \& Bethel, E.C. (2009). A meta-analysis of three types of interaction treatments in distance education. Review of Educational Research, 79(3), 1243-1289.

Blumenkrantz, D.G. \& Goldstein, M.B. (2014). Seeing college as a rite of passage: What might be possible. New Directions for Higher Education, 166, 85-94.

Bozkurt, A., \& Sharma, R. C. (2020). Emergency remote teaching in a time of global crisis due to CoronaVirus pandemic. Asian Journal of Distance Education, 15(1), i-vi. https://doi. org/10.5281/zenodo.3778083.
Cao, W., Fang, Z., Hou, G., Han, M., Xu, X., \& Zheng, J. (2020). The psychological impact of the COVID-19 epidemic on college students in China. Psychiatry Research, $287,112934$.

Chickering, A.W. \& Reisser, L. (1993). Education and identity (2nd ed.). San Francisco: Jossey-Bass.

Collins, A.J. \& Fauser, C.J.M.B. (2005). Balancing the strengths of systematic and narrative reviews. Human Reproduction Update, 11(2), 103-104.

Daniel, S.J. (2020). Education and the COVID-19 pandemic. Prospects, 1-6.

Flores, W.V. \& Rogers, K.S. (2019). Democracy, civic engagement and citizenship in higher education: Reclaiming our civic purpose. London: Lexington Book.

Gaskal, A. \& Mills, R. (2014). The quality and reputation of open, distance and e-learning: What are the challenges? Open Learning, 29(3), 190-205.

Gigliotti,R.A.(2016).Leaderasperformer; leader as human: A discursive and retrospective construction of crisis leadership. Atlantic Journal of Communication, 24(4), 185-200.

Gurukkal, R. (2020). Will COVID 19 turn higher education into another mode? Higher Education for the Future, 1-8.

Hawati, A.H. \& Jarud, R.K. (2020). Covid-19 and unequal learning. Kuala Lumpur: Khazanah Research Institute.

Holmes, C.M. \& Reid, C. (2017). A comparison study of on-campus and online learning outcomes for a research methods course. The Journal of Counsellor Preparation and Supervision, 9(2), 15.

Jalli, N. (2020). Commentary: E-learning sees no smooth sailing in Malaysia and Indonesia. Retrieved from https://www. channelnewsasia.com/news/commentary/ coronavirus-covid-19-malaysia-indonesiaschool-e-learning-online-12616944. 
Jameson, J. (2012). Leadership values, trust and negative capability: Managing the uncertainties of future English higher education. Higher Education Quarterly, 66(4), 391-414.

Jones, K. (2004). Mission drift in qualitative research, or moving toward a systematic review of qualitative studies, moving back to a more systematic narrative review. The Qualitative Report, 9(1), 95-112.

Jorgenson, D.A., Farrell, L.C., Fudge, J.L., \& Pritchard, A. (2018). College connectedness: The student perspective. Journal of the Scholarship of Teaching and Learning, 18(1), 75-95.

Kemp, N. \& Grieve, R. (2014). Face-to-face or face-to-screen? Undergraduates' opinions and test performance in classroom vs. online learning. Frontier in Psycholology. 5,1278 .

Kerr, E. (2020). Students stress out due to coronavirus, new survey finds. Retrieved from https://www.usnews.com/education/ best-colleges/articles/how-collegestudents-are-managing-coronavirus-stress.

Kumar, J.A. \& Al-Samarraie, A. (2018). MOOCs in the Malaysian higher education institutions: The instructors' perspectives. The Reference Librarian, 59(3), 163-177.

Lim, I. (2020). COVID-19: What are Malaysia's public universities doing? Online classes and more. Retrieved from https://www.malaymail.com/news/ malaysia/2020/03/16/ COVID-19-whatare-malaysias-public-universities-doingonline-classes-and-mo/ 1847071.

Mahesh, S. (2020). A need now but no replacement: Teachers share concerns about online classes during COVID-19. Retrieved from https://www.newindianexpress. com/ education/2020/may/06/a-neednow-but-no-replacement-teachers-shareconcerns-about-online-classes-duringcovid-19-2139605.html
Malaysian Communications and Multimedia Commission (MCMC). (2019). Industry performance report 2018. Retrieved from https://www.mcmc.gov.my/ skmmgovmy/ media/General/pdf/IndustryPerformanceReport-2018.pdf.

Malaysian Communications and Multimedia Commission (MCMC). (2020). 3Q 2019 Communications and Multimedia facts \& figures. Retrieved from https://www.mcmc. gov.my/skmmgovmy/media/General/ pdf/3Q_CM_2019.pdf

Malaysian Qualifications Agency (MQA). (2017). Malaysian Qualifications Framework (MQF) 2nd edition. Retrieved from https://www.mqa.gov.my/pv4/ document/ $\mathrm{mqf} / 2019 /$ Oct/updated $\% 20$ MQF\%20Ed\%202\%2024102019.pdf.

McGee, J. (2015). Breakpoint: The changing marketplace of higher education. Baltimore: The Johns Hopkins University Press.

Means B., Bakia, M., \& Murphy, R. (2014). Learning online: What research tells us about whether, when and how. New York: Routledge.

Ministry of Education, Malaysia (MoE). (2019). Statistik bilangan sekolah, murid dan guru. Retrieved from https://www.moe.gov.my/ statistik-menu/statistik-bilangan-sekolahmurid-guru.

Ministry of Higher Education, Malaysia (MoHE). (2015). Pelan pembangunan pendidikan Malaysia 2015-2025. Retrieved from https://www.moe.gov.my/muat-turun/ penerbitan-dan-jurnal/pppm-2015-2025-pt.

Ministry of Higher Education, Malaysia (MoHE). (2018). Framing Malaysian higher education 4.0: Future proof talents. Putrajaya: Ministry of Higher Education, Malaysia.

Ministry of Higher Education, Malaysia (MoHE). (2019). Statistik pendidikan tinggi 2018. Retrieved from https:// www.moe.gov.my/muat-turun/laporan- 
dan-statistik/pendidikan-tinggi/bukuperangkaan/2018-10.

Ministry of Higher Education, Malaysia(MoHE). (2020a). Garis panduan pengendalian isuisu berhubung penularan wabak COVID-19 bagi universiti awam (UA) dan institusi pengajian tinggi swasta (IPTS) mulai 18 Mac hingga 31 Mac 2020. Retrieved from http://www.apu.edu.my/sites/default/files/ surat_pemakluman_jpt_garis_panduan_ ipta_dan_ipts_covid-19.pdf.

Ministry of Higher Education, Malaysia (MoHE). (2020b). Pengendalian program akademik di universiti awam (UA) dan institusi pendidikan tinggi swasta (IPTS). http:/www.mohe.gov.my/en/media-mohe/ press-statement/1031-pengendalianprogram-akademik-di-universiti-awam-uadan-institusi-pendidikan-tinggi-swasta-ipts.

Ministry of Higher Education, Malaysia (MoHE). (2020c). Prosedur operasi standard (SOP) penghantaran pulang pelajar-pelajar institusi pendidikan tinggi (IPT) ke kampung halaman menggunakan bas. Retrieved from http://www.mohe. gov.my/en/ download/awam/manual-dangaris-panduan/570-sop-pergerakan-pulangpelajar/file.

Ministry of Higher Education, Malaysia (MoHE). (2020d). Kemasukan pelajar baharu ke institusi pengajian tinggi awam (IPTA) bagi sesi akademik 2020-2021. Retrieved from http://www.mohe.gov.my/ en/media-mohe/press-statement/1070kemasukan-pelajar-baharu-ke-institusipengajian-tinggi-awam-ipta-tahun-inibagi-sesi-akademik-2020-2021.

Ministry of Higher Education, Malaysia (MoHE). (2020e). Pengendalian aktiviti akademik di kampus institusi pendidikan tinggi semasa dan pasca perintah kawalan pergerakan. Retrieved from http://www. mohe.gov.my/en/media-mohe/pressstatement/1126-pengendalian-aktivitiakademik-di-kampus-institusi-pendidikan- tinggi-semasa-dan-pasca-perintahkawalan-pergerakan.

Muhammad, N.K. (2020). Mutu jalur lebar dalam menghadapi kejutan COVID-19. Retrieved from http://www.krinstitute. org/Views-@-Mutu_Jalur_Lebar_dalam_ Menghadapi_Kejutan_Covid-19.aspx.

Multimedia University. (2020). MMU's response to COVID-19 and MCO. Retrieved from https://www.mmu.edu.my/wp-content/ uploads/2020/04/MMU-Response-toCovid-19-and-MCO-30-April-2020.pdf

Mustafa, Z. (2020). Coping with online lectures. Retrieved from https://www.nst.com.my/ education/2020/05/594096/coping-onlinelectures.

Mustapha, R. (2020). Challenge of online teaching. Retrieved from https:/www.nst.com.my/ opinion/ columnists/2020/06/596794/challengesonline-teaching.

Palvia, S., Aeron, P., Gupta, P., Mahapatra, D., Parida, R., Rosner, R., \& Sindhi, S. (2018). Online education: Worldwide status, challenges, trends, and implications. Journal of Global Information Technology Management, 21(4), 233-241.

Public Service Department, Malaysia (2020). Jabatan Perkhidmatan Awam Malaysia. Garis panduan pengoperasian pejabat Jabatan Perkhidmatan Awam bagi tempoh semasa dan selepas perintah kawalan pergerakan. Retrieved from http:// www.ump.edu.my/covid19/Arahan $\% 20$ KPPA\% 20Bil\%202\%202020\%20-\%20 Garis\%20Panduan\%20Pengoperasian $\% 20$ Pejabat $\% 20 \quad$ Melibatkan $\% 20$ Premis $\% 20$ Jabatan $\%$ 20Perkhidmatan $\% 20$ Awam $\% 20$ Bagi\%20Tempoh\%20Semasa \%20dan $\% 20$ Selepas\%20PKPB.pdf

Paul, J. \& Jefferson, F. (2019). A comparative analysis of student performance in an online vs face-to-face environmental science course from 2009-2016. Frontier in Computer Sciences, 1(7), 1-9. 
Rachel, G. (2020). Coping with COVID-19: Distance learning and the digital divide. Kuala Lumpur: Khazanah Research Institute.

Rafidi, R. (2020). Address e-learning challenges, students urge. Retrieved from https://www. nst.com.my/education/2020/06/603056/ address-e-learning-challenges-studentsurge.

Rafidi, R. (2020). Missing the campus experience. Retrieved from https://www. nst.com.my/ education/2020/06/601793/ missing-campus-experience.

Ramadan, S. (2020). COVID-19: 9 universities arenow conducting classes online. Retrieved from https://hype.my/2020/184628/ COVID-19-9-universities-are-nowconducting-classes-online/

Regehr, C. \& Goel, V. (2020). Managing COVID-19 in a large urban researchintensive university. Journal of Loss and Trauma, 1-17.

Reich, J. \& Ruipérez-Valiente, J.A. (2019). The MOOC pivot: From teaching the world to online professional degrees. Science, 363(6423), 130-131.

Resnick, D. (2000). The virtual university and college life: Some unintended consequences for democratic citizenship. First Monday, $5(8)$.

Roddy, C., Amiet, D.L., Chung, J., Holt, C., Shaw, L., McKenzie, S., Garivaldis, F., Lodge, J.M., \& Mundy, M.E. (2017). Applying best practice online learning, teaching, and support to intensive online environments: An integrative review. Frontier Education. 2(59).

Ross, J. (2020). Pandemic confirms face to face teaching is here to stay. Retrieved from https://www.timeshighereducation. com/news/pandemic-confirms-face-faceteaching-here-stay.

Sani, R. (2020a). Students concerned over learning fully online. Retrieved from https://www.nst.com.my/education/ 2020/04/583091/students-concerned-overlearning-fully-online.

Sani, R. (2020b). Readiness for continuity in onlinelearning. Retrieved from https://www. nst. com.my/education/2020/04/584436/ readiness-continuity-online-learning

Shachar, M. \& Neumann, Y.(2010). Twenty years of research on the academic performance differences between traditional and distance learning: Summative meta-analysis and trend examination. MERLOT Journal of Online Learning and Teaching, 6(2), 318334.

Shattuck, K. (2014). Assuring quality in online education: Practices and processes at the teaching, resource and program levels. Virginia: Stylus Publishing LLC.

Taylor, J. (2020). Coronavirus and the NBN: Will your broadband be up to speed if you have to work from home? Retrieved from https:/www.theguardian.com/technology/ 2020/mar/13/coronavirus-and-the-nbnwill-your-broadband-be-up-to-speed-ifyou-have-to-work-from-home.

Teoh, P. (2020). COVID-19: Universities activate e-learning mode. Retrieved from https://www.nst.com.my/news/nation/ 2020/03/574766/COVID-19-universitiesactivate-e-learning-mode

Tinto, V. (2011). Completing college: Rethinking institutional action. Chicago, IL: University of Chicago Press.

UNESCO. (2020). COVID-19 educational disruption and response. Retrieved from https://en.unesco.org/themes/educationemergencies/coronavirus-school-closures

Universiti Kebangsaan Malaysia (UKM). (2020). Pekeliling akademik bil. 11/2020. COVID-19: Penambahbaikan pelaksanaan peperiksaan akhir semester II sesi akademik 2019-2020. Retrieved from https://www.ukm.my/portal/wp-content/ uploads/2020/05/ GarisPanduanBekerja4-5. pdf 
Universiti Malaya (UM). (2020). Garis panduan pengajaran dan pembelajaran dalam talian semasa pandemik. Retrieved from https:/umacademic.um.edu.my/img/files/ Covid $\%$ 20News/Garis\%20Panduan $\% 20$ PdP\%20Online/Garis\%20Panduan\%20 Pengajaran\%20Dan\%20Pembelajaran $\% 20$ Dala m \% 20 Talian $\% 20 \mathrm{Se}$ a sa $\% 20$ Pandemik\%20COVID-19.pdf.

Universiti Malaysia Sarawak (UNIMAS). (2020). COVID-19 response: A quick guide for UNIMAS academics. Retrieved from http://www.calm.unimas. my/COVID19.

Universiti Sains Malaysia (USM). (2020a). Overview of future scenario planning in light of COVID-19. Retrieved from https://www.usm.my/index.php/covid19/ announcements/ 766-19-march-2020overview-of-future-scenario-planning-inlight-of-covid-19.

Universiti Sains Malaysia (USM). (2020b). Response and readiness plan for COVID-19 pandemic and other infectious disease outbreaks. Retrieved from https://www. usm.my/ index.php/covid19.

Vegas, E. (2020). School closures, government responses, and learning inequality around the world during COVID-19. Retrieved from https://www.brookings.edu/research/ school-closures-government-responsesandlearning-inequality-around-the-worldduring-covid-19/.

Versteijlen, M., Salgado, F.P., Groesbeek, M.J., \& Counotte, A. (2017). Pros and cons of online education as a measure to reduce carbon emissions in higher education in the Netherlands. Current Opinion in Environmental Sustainability, 28, 80-89 .

Wagner, S.C., Garippo, S.J., \& Lovaas, P. (2011). A longitudinal comparison of online versus traditional instruction. MERLOT Journal of Online Learning and Teaching, 7(1), 68-73.

Wang, C. \& Zhao, H. (2020). The impact of COVID-19 on anxiety in Chinese university students. Frontiers in Psychology, 11, 1168.

Weissman, S. (2020). Diverse webinars explore new questions facing higher education amid COVID-19. Diverse: Issues in Higher Education, 37(6), 26-28.

Zhong, R. (2020). The coronavirus exposes education's digital divide. Retrieved from https:// www.nytimes.com/2020/03/17/ technology/china-schools- coronavirus. html. 